\title{
$\mathrm{KCNT1}$ 돌연변이가 확인된 영아 이동성 부분 발작 뇌전증 환아에서의 Quinidine 치료를 시도한 영아 1예
}

연세대학교 세브란스 어린이병원 소아청소년과 소아신경과 ${ }^{1}$, 연세대학교 진단검사의학과 ${ }^{2}$

지나리 ${ }^{1} \cdot$ 고아라 $^{1} \cdot$ 김세희 $^{1} \cdot$ 이준수 $^{1} \cdot$ 김흥동 $^{1} \cdot$ 이승태 $^{2} \cdot$ 최종락 $^{2} \cdot$ 강훈철 $^{1}$

\section{Quinidine Trial in a Patient with Epilepsy of Infancy with Migrating Focal Seizure and KCNT1 Mutation}

Epilepsy of infancy with migrating focal seizure (MFEI) is an early-onset epileptic encephalopathy characterized by randomly migrating focal seizures and psychomotor deterioration. It is associated with mutations in a variety of genes, with potassium sodium-activated channel subfamily T member 1 (KCNT1) being an example. Previously reported KCNT1 mutations in MFEI are gain-of-function mutations. Therefore, quinidine therapy targeted at reduction of pathologically increased KCNT1 channel-mediated potassium conductance has been proposed as a target treatment for MEFI with KCNT1 mutation. The authors report a case involving a patient with MFEI and a missense mutation in KCNT1 (c.7129G>A; p.Phe346Leu) treated with quinidine therapy. Seizure activity was poorly responsive to quinidine.

Key Words: Epilepsy of infancy with migrating focal seizure, KCNT1 mutation, Quinidine
Nalee Jee, $M D^{1}$, Ara Ko, MD', Se Hee Kim, MD', Joon Soo Lee, MD, PhD', Heung Dong Kim, MD,PhD', Seung-Tae Lee ${ }^{2}$, Jong Rak Choi, MD, $\mathrm{PhD}^{2}$, Hoon Chul Kang, MD, PhD ${ }^{1}$

${ }^{1}$ Division of Pediatric Neurology, Department of Pediatrics, Severance Children's Hospital, Yonsei University College of Medicine, Seoul, Korea, ${ }^{2}$ Department of Laboratory Medicine, Yonsei University College of Medicine, Seoul, Korea

\section{Introduction}

Epilepsy of infancy with migrating focal seizures (MFEI) is a rare, early onset epileptic encephalopathy characterized by pharmacoresistant epilepsy and arrest of psychomotor development in the first 6 months of life ${ }^{1-4)}$. Interictal electroencephalography (EEG) demonstrates multifocal spikes and slowing, with ictal EEG discharges arising from various areas of both hemispheres and migrating from one brain region to another.

Several genetic causes of MFEI have been identified, including mutations in the potassium sodium-activated channel subfamily T member 1 (KCNT1) phospholipase C beta $1(P L C B 1)^{6}$, sodium voltage-gated channel alpha subunit1 $(S C N 1 A)^{7)}$, solute carrier family 25 member $22(S L C 25 A 22)^{6}$, and TBC1 domain family member $24(T B C 1 D 24)^{8)}$. More recently, de novo mutations in the KCNT1 gene (also known as Slo2.2 or Slack) were described as disease-causing in approximately $40 \%$ to $50 \%$ of all MFEI patients ${ }^{5,9,10)}$. Mutations result in KCNT1 channel gain of function. Importantly, reported KCNT1 mutations in MFEI are gain-of-function mutations leading to constitutive activation of the channel; therefore, pharmacological inhibition of KCNT1 is a potential therapeutic target ${ }^{5)}$.
This research was supported by a grant of the Korea Health Technology R\&D Project through the Korea Health Industry Development Institute (KHIDI), funded by the Ministry of Health \& Welfare, Republic of Korea (grant number: HI15C1601).

This paper is a poster presented at the Fall Meeting of the Pediatric Society of Korea in 2016.

Submitted: 27 July, 2017

Revised: 12 August, 2017

Accepted: 30 August, 2017

Correspondence to Hoon-Chul Kang, M.D, PhD Department of Pediatrics, Severance Children's Hospital, Epilepsy Research Institute Yonsei University College of Medicine, 50-1 Yonsei-ro, Seodaemun-gu, Seoul 03722, Korea

Tel: +82-2-2228-2050, Fax: +82-2-393-9118

E-mail: hipo0207@yuhs.ac

Copyright $\odot 2017$ by The Korean Child Neurology Society http://www.cns.or.kr 
In this report, we describe a patient with MFEI and KCNT1 mutation (c.7129G>A; p.Phe346Leu) who underwent a trial of quinidine.

\section{Case report}

A 3-month-old boy was admitted to our hospital via the emergency center for 5 generalized tonic seizures that lasted 1 min to 2 min for 1 day. He was fitst child from nonconsanguineous Korean parent; He was born at fullterm and weighted 2.6 $\mathrm{kg}$. There was no family history of seizures or other neurological disorders. EEG demonstrated clinical and subclinical seizures associated with ictal discharges arising independently from the left frontal, left temporal, or right temporal areas. Brain magnetic resonance imaging revealed no abnormal findings. EEG demonstrated a pattern of MFEI; with focal seizures migrating between left and right hemispheres (Fig.1). Therefore, the patient was started on antiepileptic drugs (AEDs).

Trials of multiple medications alone and in various combinations, including phenobarbital, levetiracetam, phenytoin, topiramate, valproic acid, gabapentin, and clobazam, were without effect on seizure frequency, and the patient continued to have the patient has daily seizures of tonic seizures involving the left, right, or both sides of the body, 10 to 20 times a day, and about 1 or 2 of these seizures last longer than 20 minutes and required intravenous injection of benzodiazepine or other AEDs. When placed on continuous EEG monitoring, subclinical seizures were also frequently detected. A ketogenic diet was also attempted but was, however, abandoned after 2 months due to lack of efficacy.

Metabolic and imaging work-up were negative. A gene panel was sent out for epileptic encephalopathy, and revealed that the patient had a heterozygous mutation in the KCNT1 (c.7129G>A;

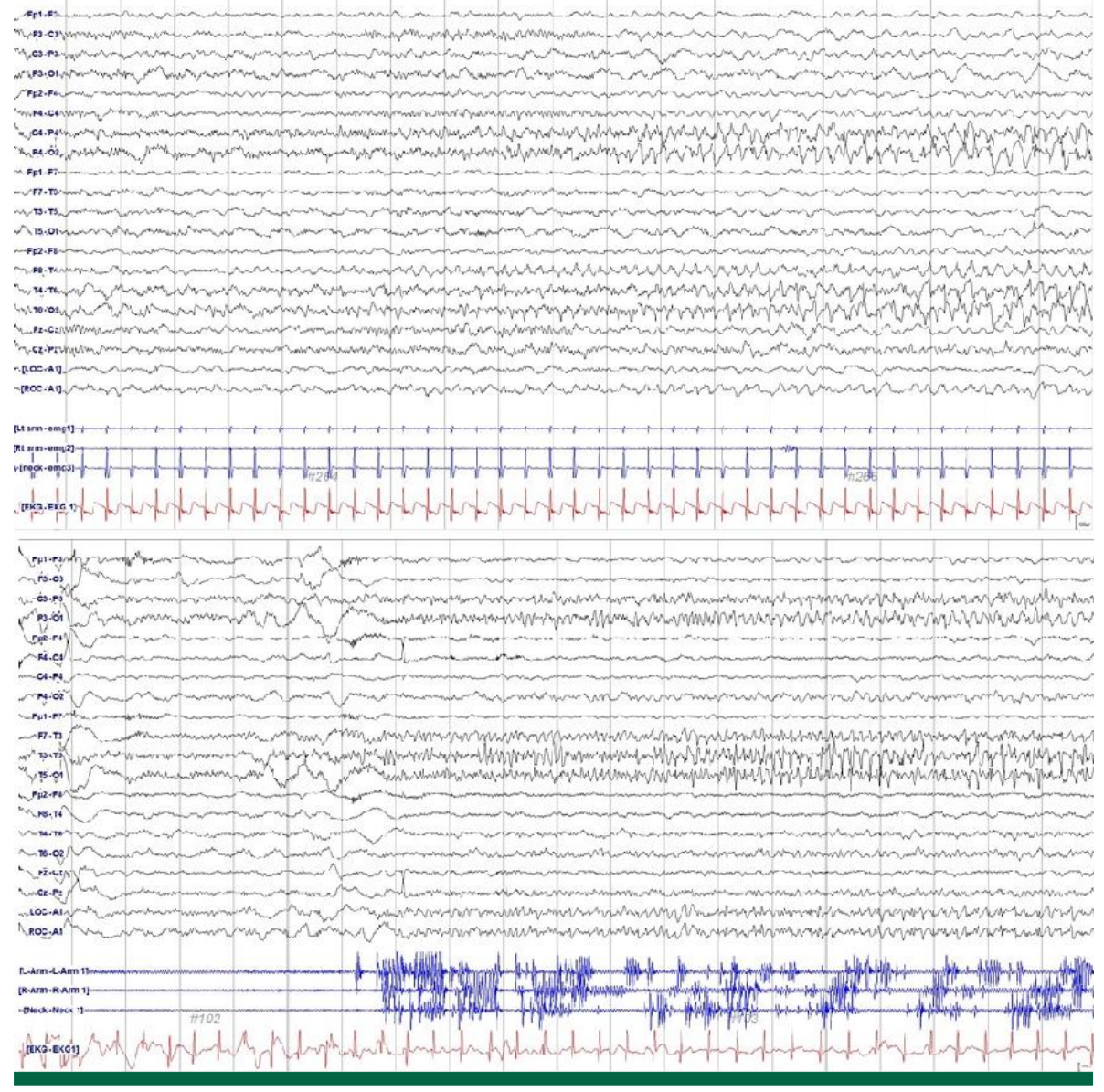

Fig. 1. Electroencephalogram at initial presentation(Ictal phase) Electroencephalogram at initial presentation. (A) Focal seizure originating from right temporal lobe. (B) Several seconds later, seizure has migrated to the left. clinically presenting as desaturation, vacant staring with eyeball fixation, sometimes with both arm elevation, which are associated with ictal rhythmic discharges evolving from Rt. temporal (10 times) or Lt. temporal (13 times) areas, and then spreading to ipsilateral diffuse hemisphere, sometimes speading ton whole brain. 
p.Phe346Leu). His parents were also tested; however, they did not carry such a mutation, confirming that the mutation of KCNT1 gene in the patient was a de novo mutation (Fig. 2).

After genetic diagnosis of KCNT1 encephalopathy, quinidine therapy was attempted. He was started on $11 \mathrm{mg} / \mathrm{kg} /$ day of quinidine with gradual dose increase to $54.2 \mathrm{mg} / \mathrm{kg} /$ day $(320$ $\mathrm{mg} /$ day), but was stopped after 10 days of trial due to lack of response and tremor that appeared to be a side effect (Table 1).

To date, the patient (now 20 months old) experiences tonic seizures of either or both sides of the body 10 to 20 times per day, with approximately 1 or 2 of these seizures lasting longer than $20 \mathrm{~min}$ and requiring adjuvant rectal benzodiazepine injections in addition to 4 oral AEDs (barbiturate, levetriacetam, stitipentol, topiramate). The head circumference of the patient was normal ( $42 \mathrm{~cm}, 50$ percentile) at the onset of disease, but

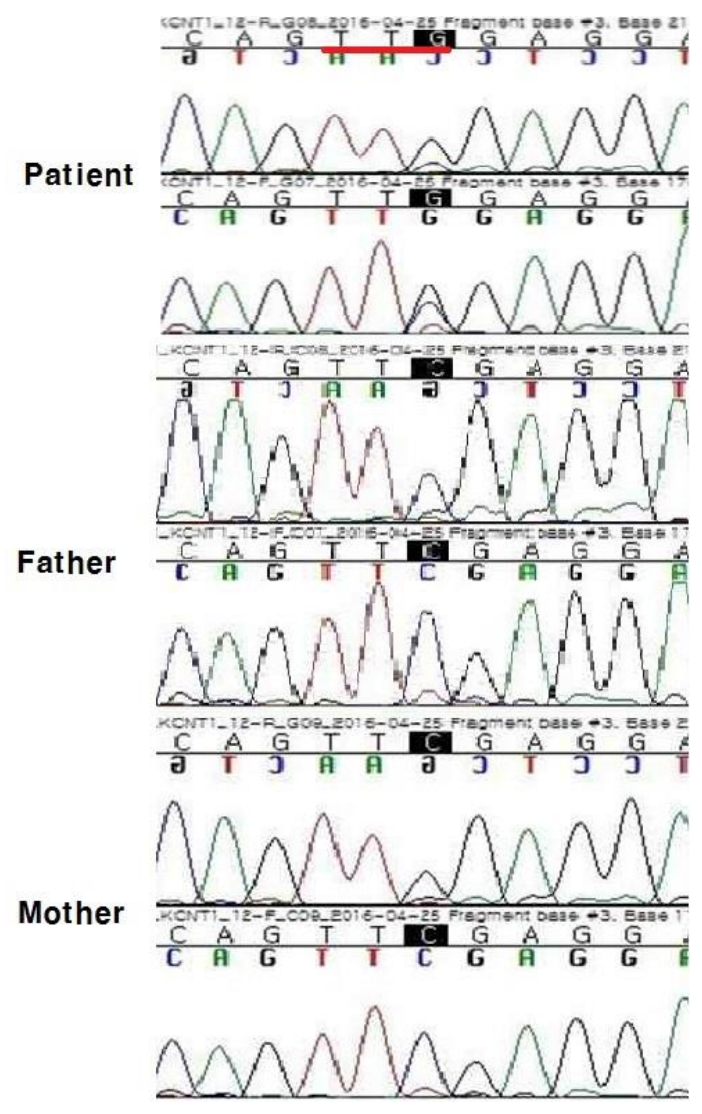

Fig. 2. Sequence chromatogram and alignment to the reference sequence revealing variation. KCNT1 (likely pathogenic), a missense mutation that was not previously reported was observed as a heterozygote, and a family test was performed. The mutation was not detected in the parent sample and was confirmed as a de novo mutation. A mutation that has not been reported so far or is not reported in the normal population, and the KCNT1 is a de novo mutation in the autosomal dominent genetic pattern in epileptic encephalotpathy, which may be a genetic cause in this patient. now it is microcephaly ( $45 \mathrm{~cm},<3$ percentile). He has exhibited profound developmental regression since the onset of these seizures.

\section{Discussion}

We report a case involving a patient with MFEI and mutation in $K C N T 1$, who demonstrated no response to quinidine therapy. The identification of KCNT1 mutations as a genetic cause for MFEI and autosomal dominant nocturnal frontal lobe epilepsy suggests that these conditions may be treatable using a drug that specifically targets the KCNT1 channel. Quinidine therapy has been introduced as a targeted therapy in MFEI with KCNT1 mutation to reduce increased KCNT1 channel-mediated potassium conductance. KCNT1 encodes the pore-forming alpha subunit of the potassium channel ${ }^{11}$; quinidine acts to these block pores. Therefore, quinidine is a potential therapeutic agent for individuals with $K C N T 1$ mutation.

Previous studies have demonstrated that quinidine reduces the conductance of the activated channel by a gain-of-function mutation of $K C N T 1$ in vitro ${ }^{12,13)}$. Additionally, quinidine treatment has been trialed in three patients with KCNT1 mutations for whom treatment with standard antiepileptic therapies had been unsuccessful. Two patients with malignant migrating focal seizures of infancy experienced marked improvement in seizure control following quinidine administration. However, our patient did not experience the same effect as in vitro studies or other clinical cases.

There are several reasons why quinidine is not effective against the KCNT1 mutation when applied to actual patients. The first is that the exact concentration of quinidine needed to be effective in the brain is unknown. KCNT1 is highly expressed in both neurons and cardiomyocytes in which quinidine acts as an effective antiarrhythmic agent. However, previous studies have shown that quinidine does not accumulate well in the cerebrospinal fluid, and that levels change with interactions with $\mathrm{AEDs}^{14,15)}$. Thus, quinidine levels in the brains of patients taking AEDs may be lower than serum levels of those taking it to treat arrhythmias. However, it remains unclear whether quinidine can pass the blood-brain barrier and what levels are effective once it

Table 1. Timeline of Treatment

\begin{tabular}{lccc}
\hline & Quinidine dose & Quinidine level & Seizures/day \\
\hline Day 1-3 & $11 \mathrm{mg} / \mathrm{kg} /$ day & $0.6 \mu \mathrm{g} / \mathrm{mL}$ & 10 \\
Day 4-6 & $40 \mathrm{mg} / \mathrm{kg} /$ day & $2.4 \mu \mathrm{g} / \mathrm{mL}$ & 13 \\
Day 7-10 & $54.2 \mathrm{mg} / \mathrm{kg} /$ day & $1.7 \mu \mathrm{g} / \mathrm{mL}$ & 8
\end{tabular}


has reached the brain. QT prolongation may occur due to the side effects of quinidine, which makes it difficult to determine an appropriate level because quinidine cannot be tried in unlimited doses until it becomes effective. Second, MFEI patients with KCNT1 mutations who undergo quinidine trials have already failed many conventional AEDs. Most are taking multiple AEDs, which can also affect quinidine levels. In addition, because seizures have been intractable for a certain period of time, it is likely that morphological changes have already occurred in the brain, regardless of the presence of KCNT1 mutation $^{16)}$. Third, because phenotype and genotype are not always consistent, unlike previous reports describing the effectiveness of quinidine for MFEI, it may not have been effective in our patient. It is necessary to confirm that the treatment for the mutation in the genotype applies to the phenotype.

The isolation of human induced pluripotent stem cells (iPSCs) offers a novel strategy for modeling human disease, recent studies have reported the derivation and differentiation of disease-specific human iPSCs. Therefore, iPSCs may represent a possible investigative avenue in this disease model ${ }^{17,18)}$. It is also possible to perform experiments in an animal-based model with KCNT1 using gene editing through clustered regularly interspaced short palindromic repeat (CRISPR)-Cas9 (CRISPR associated protein 9) technology $y^{19,20)}$.

Seizure frequency in our patient was not decreased by quinidine therapy. In conclusion, this case suggests that quinidine is not always an effective treatment for individuals with epilepsy of infancy with migrating focal seizures and KCNT1 mutation. To tailor therapy to genetic mutations in patients, therefore, it will be necessary to conduct preliminary studies on how genotypes are actually expressed as phenotypes. Further studies are necessary to investigate exact effective doses and serum levels for the use of quinidine in patients with KCNT1 mutation, and to study whether the effect will be different when using preemptive targeting agents in addition to conventional AEDs.

\section{요약}

영아이동성 부분 발작 뇌전증(MEFI)은 여러 부위에 무작위적으로 발생하는 이동성 부분 발작과 발달이상을 특징으로 하는 조기 발병 뇌증이다. 이는 다양한 유전자의 돌연변이와 연관되어있고 그 중 하나 로 $K C N T 1$ 돌연변이가 있다. 이전 연구에 따르며 MEFI의 KCNT1 돌 연변이는 기능획득 돌연변이로 알려져 있다. 따라서 $K C N T 1$ 돌연변이 를 가진 MEFI 환자의 표적 치료로서 병적으로 증가 된 $K C N T 1$ 채널 매개 칼륨 전도성의 감소를 일으키는 퀴니딘 치료가 제안되었다. 이
증례에서는 $K C N T 1$ 유전자에 결실 돌연변이 $(\mathrm{c} .7129 \mathrm{G} \rightarrow \mathrm{A} ; \mathrm{p}$. Phe346Leu)가 MEFI 있는 환자에게 퀴니딘 치료를 시도하여 보고하 는 바이다. 특이 출생력 과거력 및 가족력없는 환아로 생후 3 개월에 발생한 전신 긴장성 발작을 주소로 내원하였다. 시행한 뇌파에서 왼 쪽 후두엽, 오른쪽 후두엽 및 왼쪽 전두엽 부위에서 이동성으로 편측 뇌에서 발생하는 간질파 양상을 보여 영아이동성 부분 발작 뇌전증으 로 진단되었으며 phenobarbital, levetiracetam, phenytoin, topiramate, valproic acid, gabapentin, clobazam 등의 AED를 사 용하였으나 발작빈도에 변화가 보이지 않았으며 케톤생성식이를 2달 간 시도하였으나 이 또한 발작빈도에 영양을 주지 않았다. 이 환자에 서 $K C N T 1$ 결실 돌연변이가 있음을 유전자 검사를 통하여 확인하여 이에 대한 표적치료로 퀴니딘을 사용하였으며 발작빈도에 미미한 영 향을 주었으나 진전등의 부작용이 발생하여 사용을 중단하였다. 현재 약물 복용을 지속하며 간헐적으로 직장으로 diazepam을 주입하여 경련을 조절 중이다. 영아이동성 부분 발작 뇌전증에서 퀴니딘의 치 료가 모든 환자에서 효과가 있지 않음을 확인하였으며 개개인에 맞춤 치료를 지향하기 위한 선행연구가 필요할 것으로 생각된다.

\section{References}

1) Coppola G, Plouin P, Chiron C, Robain O, Dulac O. Migrating partial seizures in infancy: a malignant disorder with developmental arrest. Epilepsia 1995;36:1017-24.

2) Coppola G. Malignant migrating partial seizures in infancy: an epilepsy syndrome of unknown etiology. Epilepsia 2009;50 Suppl 5:49-51.

3) Marsh E, Melamed SE, Barron T, Clancy RR. Migrating partial seizures in infancy: expanding the phenotype of a rare seizure syndrome. Epilepsia 2005;46:568-72.

4) McTague A, Appleton R, Avula S, Cross JH, King MD, Jacques TS, et al. Migrating partial seizures of infancy: expansion of the electroclinical, radiological and pathological disease spectrum. Brain 2013;136:1578-91.

5) Barcia G, Fleming MR, Deligniere A, Gazula VR, Brown MR, Langouet M, et al. De novo gain-of-function KCNT1 channel mutations cause malignant migrating partial seizures of infancy. Nat Genet 2012;44:1255-9.

6) Poduri A, Chopra SS, Neilan EG, Elhosary PC, Kurian MA, Meyer E, et al. Homozygous PLCB1 deletion associated with malignant migrating partial seizures in infancy. Epilepsia 2012;53:E146-50.

7) Freilich ER, Jones JM, Gaillard WD, Conry JA, Tsuchida TN, Reyes C, et al. Novel SCN1A mutation in a proband with malignant migrating partial seizures of infancy. Arch Neurol 2011;68:665-71.

8) Milh M, Falace A, Villeneuve N, Vanni N, Cacciagli P, Assereto S, et al. Novel compound heterozygous mutations in TBC1D24 cause familial malignant migrating partial seizures of infancy. Hum Mutat 2013;34:869-72.

9) De Filippo MR, Rizzo F, Marchese G, Giurato G, Nassa G, Ravo 
M, et al. Lack of pathogenic mutations in six patients with MMPSI. Epilepsy Res 2014;108:340-4.

10) Ishii A, Shioda M, Okumura A, Kidokoro H, Sakauchi M, Shimada S, et al. A recurrent KCNT1 mutation in two sporadic cases with malignant migrating partial seizures in infancy. Gene 2013;531:467-71.

11) Yuan A, Santi CM, Wei A, WangZW, PollakK, Nonet M, et al. The sodium-activated potassium channel is encoded by a member of the Slo gene family. Neuron 2003;37:765-73.

12) Milligan CJ, Li M, Gazina EV, Heron SE, Nair U, Trager C, et al. KCNT1 gain of function in 2 epilepsy phenotypes is reversed by quinidine. Ann Neurol 2014;75:581-90.

13) Mikati MA, Jiang YH, Carboni M, Shashi V, Petrovski S, Spillmann R, et al. Quinidine in the treatment of KCNT1-positive epilepsies. Ann Neurol 2015;78:995-9.

14) Ochs HR, Greenblatt DJ, Lloyd BL, Woo E, Sonntag M, Smith TW. Entry of quinidine into cerebrospinal fluid. Am Heart J 1980;100:341-6.
15) Data JL, Wilkinson GR, Nies AS. Interaction of quinidine with anticonvulsant drugs. N Engl J Med 1976;294:699-702.

16) Ben-Ari Y, Holmes GL. Effects of seizures on developmental processes in the immature brain. Lancet Neurol 2006;5:1055-63.

17) Kilpinen H, Goncalves A, Leha A, Afzal V, Alasoo K, Ashford S, et al. Common genetic variation drives molecular heterogeneity in human iPSCs. Nature 2017;546:370-5.

18) Lee G, Papapetrou EP, Kim H, Chambers SM, Tomishima MJ, Fasano CA, et al. Modelling pathogenesis and treatment of familial dysautonomia using patient-specific iPSCs. Nature 2009;461:402-6.

19) Hsu PD, Lander ES, Zhang F. Development and applications of CRISPR-Cas9 for genome engineering. Cell 2014;157:1262-78.

20) Suzuki K, Tsunekawa Y, Hernandez-Benitez R, Wu J, Zhu J, Kim EJ, et al. In vivo genome editing via CRISPR/Cas9 mediated homology-independent targeted integration. Nature 2016;540:144-9. 